\title{
人工膝関節置換術の術後関節位置覚の推移と それに影響を与える因子の抽出
}

\section{Perioperative Changes in Proprioception after Total Knee Arthroplasty and Identification of Factors Affecting it}

\author{
澤田 優子1）＼cjkstart赤木 将男2）＼cjkstart浜西 千秋2）＼cjkstart朝田 滋貴2) \\ 森 成志 ${ }^{2}$ 丸尾 優子1) 福田 寛二1) \\ Yuko SAWADA ${ }^{1)}$, MASAo AKAGI ${ }^{2)}$, ChiAKI HAMANISHI ${ }^{2)}$, SHigeKI ASADA ${ }^{2)}$, \\ SHIGESHI MORI ${ }^{2)}$, YUKO MARUO ${ }^{1)}$, KANJI FUKUDA ${ }^{3)}$ \\ 1) Department of Rehabilitation, Kinki University School of Medicine: 377-2 Ohno-Higashi, Osaka-Sayama City, Osaka 589- \\ 8511, Japan.TEL +8172-366-0221E-mailsawada@reha.med.kindai.ac.jp \\ 2) Department of Orthpaedic Surgery, Kinki University School of Medicine
}

Rigakuryoho Kagaku 23(2): 279-283, 2008. Submitted Sep. 27, 2007. Accepted Nov. 30, 2007.

ABSTRACT: The purpose of this study was to clarify the longitudinal perioperative change in knee proprioception after total knee arthroplasty (TKA) and to identify factors affecting it. Thirty knees of patients with TKA for osteoarthritis or rheumatoid arthritis were prospectively analyzed. Preoperative score of knee proprioception averaged 19.0 ( \pm 3.9). Mean score of knee proprioception was $6.2( \pm 3.0)$ three weeks after the operation $(\mathrm{p}<0.01)$ and recovered with time, reaching a score comparable to the preoperative one three months after surgery $(18.1 \pm 4.1)$. Factors affecting the decrease in the score three weeks after surgery included age at time of operation, preoperative JOA knee score, BMI, perioperative blood loss, operating time, and length of skin incision. Maintaining and improving preoperative daily activity of the patients seems to be important for quick postoperative recovery of proprioception after TKA, when preoperative rehabilitation could effectively intervene.

Key words: total knee arthroplasty, proprioception, affecting factors

要旨: 本研究の目的は, 人工膝関節置換術における術後関節位置覚の経時的推移を明らかにし, 膝関節位置覚の変化 に影響を与える因子を抽出することである。人工膝関節置換術（以下TKA）を施行した患者 30 名を対象とした。術前 後の位置覚を測定, 得点化し, 推移を明らかにした。その結果位置覚得点は3週で最も低下し, その後時間の経過に伴 い改善することが分かった。術後3週での関節位置覚低下に関与する要因を検討するため, 位置覚を高值群, 中間群, 低值群の3群に分けて関連要因を検討した。その結果, 関節位置覚得点が低い群では, 年齢が高い, 日本整形外科学会 膝関節スコアが低い, BMIが高い, 術中・術後の出血量が多い, 術時間が長い, 皮切が大きい傾向が認められた。術 前の日常生活活動性の維持, および改善が術後の膝関節位置覚の早期回復に重要と思われた。

キーワード：人工膝関節置換術，関節位置覚，影響因子

1)近畿大学医学部附属病院 リハビリテーション部：大阪府大阪狭山市大野東377-2（テ589-8511）TEL 072-366-0221

2) 近畿大学 医学部整形外科

受付日 2007年9月27日＼cjkstart受理日２007年11月30日 


\section{I. 緒 言}

身体の空間での位置や運動の感覚に関連する固有感 覚の代表的なものの一つに関節位置覚がある。関節位 置覚の受容器は筋や腱, 皮膚, 関節包, 靭帯など関節 および関節周囲に多く分布している1)。術後, 関節位置 覚は手術侵襲，関節周囲組織の腫脹などにより傷害さ れ, 歩容の変化を来すと考えられる。人間は歩行, 立 ち座り, 階段昇降などのADLに必要な基本動作におい て関節の位置覚を多用しており, 術後の早期復帰を目 指すには, 手術により傷害された関節位置覚の早期回 復が望まれる。

変形性膝関節に対して人工膝関節全置換術を施行し た場合, 関節内の固有感覚受容器は大きく切除される。 また, 術後は手術侵襲により関節周囲組織の著しい腫 張を生じる. このため, 術直後は固有感覚の著しい低 下が予想される。切除され傷害を受けた固有感覚受容 器を有する組織にかわり, 残存した筋・靭帯組織が代 償として働き, 正常な関節の位置覚を取り戻すまでに はある程度の時間を要すると考えられる。術後リハビ リテーションにおいては, 早期に積極的な介入が必要 とされており 2), 膝関節可動域や膝関節周囲筋力のみ ならず関節位置覚をいかに早く回復させ, 本来の社会 生活に復帰させるかも重要な点の一つである。特に在 院日数の短縮が求められ早期退院が要求される昨今の 医療情勢にあっては, 関節位置覚の回復は転倒予防の 観点からも注目すべきリハビリテーション項目の一つ と考えられる。しかし, 人工膝関節術後の関節位置覚 の自然経過および関節位置覚の回復に影響を与える因 子については十分な検討がなされてきていない。

本研究の目的は, 人工膝関節置換術における術前後 関節位置覚の経時的推移を明らかにし, 膝関節位置覚 の変化に影響を与える因子を抽出することである。

\section{II. 方 法}

\section{1. 対象}

平成 16 年 9 月 1 日から 17 年 3 月 30 日の間に K大学附属 病院整形外科において変形性関節症に対し, 人工膝関 節全置換術（以下TKA）を施行した患者のうち，検查・ 測定, 訓練の遂行に支障がない者連続30名を対象とし た（男性 2 名, 女性 28 名)。全例, ACL, PCL を切除す る術式であった。平均年齢 $73.1 \pm 7.1$ 歳, 平均身長 149.0 $\pm 5.0 \mathrm{~cm}$, 平均体重 $63.7 \pm 11.4 \mathrm{~kg}$, 平均BMI $28.5 \pm 5.1$ で あった。研究にあたっては対象患者の理解と同意, お
よび主治医の許可を得た。検査・測定は同一の理学療 法士が行った。理学療法の進行は, 当院で使用してい るクリティカルパス（術後1日目から歩行開始，1週間 後階段昇降，2週間後自宅退院）に準拠した。

\section{2. 方法}

調查項目は, 対象患者の性別, 年齢, 身体計測值（体 重, 身長, BMI), 術中出血量, 術時間, 皮切長, 日本 整形外科学会膝関節評価スコア (JOA スコア: 歩行能 力, 階段昇降能力, 膝関節可動域, 腫脹の有無), 関節 位置覚得点とした。関節位置覚得点の測定時期は, 術 前, 術後 3 週 (退院時), 術後6 週, 術後 3 ケ月, 術後6 月の計 5 回とした。

座位での膝屈曲 $30^{\circ}, 60^{\circ}$, および腹臥位での膝屈曲 $30^{\circ}, 60^{\circ}$ の 4 種類の肢位で関節位置覚測定を行った。測 定姿勢は, 重力の影響をバイアスとしないため, 座位, 腹臥位の2姿勢で行った。また，方法の妥当性，信頼性 を健常者を対象とした事前テストで確認した。関節位 置覚は以下の方法にて定量化した。すなわち, 術側膝 を屈曲 $30^{\circ}, 60^{\circ}$ で保持し非術側を同じ位置に持ってく るよう指示した。測定は検査者がランダムに検査側の 下肢を測定角度に保持し，その状態で「膝の角度を同 じ位置にしてください」と指示し，停止した状態で測 定側の膝の角度を測定した。術側と非術側の屈曲角度 の差を定量的に表すため, 下記の方法で数值化した。 術側と非術側膝の屈曲角度の差が $5^{\circ}$ 未満を 2 点, $5^{\circ}$ 以 上 $10^{\circ}$ 未満を 1 点, $10^{\circ}$ 以上を 0 点とした。各々の肢位で 測定を 3 回繰り返し, 得点を合計した（満点 24 点）。角 度の測定は酒井医療社製，東大型角度計を使用し，関 節可動域の基本軸と移動軸は日本整形外科学会及び日 本リハビリテーション医学会の「関節可動域表示なら びに測定法」（1995年）に従った。

1）術前後の膝関節位置覚得点の平均值を t-testを用 いて比較した。

2) 術後 3 週の膝関節位置覚得点を目的変数, 年齢, BMI, 術前JOAスコア (項目別点数および合計点数) を 説明変数とした一要因一元配置分散分析を行った。術 後 3 週の関節位置覚得点が 6 点未満を低值群, 7 から 10 点未満を中間群，10 点以上を高值群とした。

有意水準は $5 \%$ 未満とした。統計処理には統計処理ソ フトウェアSPSS12.0 for windowsを用いた。

\section{III. 結 果}

術前後の膝関節位置覚の推移を表 1 に示す。術前後 
の関節位置覚の得点は, 術後 3 週で最も低下した。術前 では 18.9 点であったのに対し, 術後 3 週で 6.1 点と大き く低下し, 術後 6 週で 14.1 点と改善し, 術後3 月月で 18.1 点とほぼ術前位置覚得点と同等に回復し, 術後6 月月で は 19.8 点と術前より改善の傾向が認められた。各々の 時期の平均値の差を $\mathrm{t}$-test で比較したところ, 全てに 5 \%水準で有意な差が見られた。

手術データは, 術中出血量 $355.7 \pm 217.7 \mathrm{~g}$, 術後出血 量 $590.5 \pm 207.9 \mathrm{~g}$, 手術時間 $176.0 \pm 37.8$ 分, 皮切長 11.0 $\pm 2.0 \mathrm{~cm}$ であった。

JOA スコアの変化を表 2 に示す。歩行能力について は, 術前 14.5 点であったが, 術後 3 週で 16.0 点, 術後 6 週で 17.9 点, 術後 3 ケ月で 20.9 点, 術後 6 ケ月で 20.7 点と 大きく改善した。階段昇降能力は, 術前 9.8 点, 術後 3 週で 12.4 点, 術後 6 週で 15.2 点, 術後 3 ケ月で 16.0 点, 術 後6ケ月で 17.9 点と歩行能力と同様の改善を示した。膝 関節可動域では, 術前 24.3 点に対し, 術後 3 週で 23.9 点, 術後 6 週で 24.0 点, 術後 3 ケ月と 24.1 点, 術後 6 ケ月で 25.3 点と大きな変化は見られなかったが, 術前に比べ て, 術後6ケ月の時点では, 1 点の改善を示した。膝関 節腫脹については, 術前 8.1 点, 術後 3 週 8.1 点, 術後 6 週 6.6 点, 術後 3 个月 8.3 点, 術後 6 个月 8.8 点之可動域と 同様大きな変化は見られなかった。

合計点の推移を見ると, 術前 56.7 点, 術後 3 週 60.3 点, 術後 6 週 63.6 点, 術後 3 个月 69.3 点, 術後 6 个月 72.8 点と 時間経過に伴い, 改善を示した。

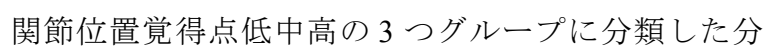
散分析の結果, JOA スコアの階段, 腫脹, 合計におい て, $5 \%$ 水準で有意な主効果がみられた（表 3 )。

多重比較 (TukeyのHSD 法) の結果, 階段では低值群 と中間群, 低值群と高值群部の間に $5 \%$ 水準で有意差が みられ, 高値群, 中間群の得点が高かった。腫脹, 合 計においても同様の傾向が見られた（表4）。

\section{IV. 考 察}

本研究では, 膝関節置換術前後の関節位置覚の変化 を明らかにした。関節位置覚の研究は股関節, 膝関節 で行われているが，人工関節置換術については股関節 での検討が多い。中川らは3)人工股関節全置換術 (THA) を実施された 108 名を被験者とし関節位置覚について 検討しており術後の変化を明らかにしている。田篭ら は4) 右人工股関節全置換術（THA）再々置換術を受け た者を対象に股関節の関節位置覚を測定しており, 関 節位置覚の低下と脱臼との関連を示している。股関節
表1 術前後の関節位置覚得点の変化

\begin{tabular}{lcc}
\hline & 平均值 & 標準偏差 \\
\hline 術前 & 18.97 & 3.94 \\
術後 3 週 & 6.17 & 2.98 \\
術後 6 週 & 14.45 & 4.27 \\
術後 3ケ月 & 18.14 & 4.13 \\
術後 6ケ月 & 19.76 & 4.11
\end{tabular}

※各々の時期の平均值の差を t-test で比較し たところ，全ての経過で有意な差が見られ た (5\%水準).

表2 術前後のJOAスコアの変化（平均值）

\begin{tabular}{lccccc}
\hline & 術前 & \multicolumn{4}{c}{ 術後 } \\
\cline { 3 - 6 } & & 3 週 & 6 週 & 3ヶ月 & 6ヶ月 \\
\hline 歩行 & 14.5 & 16.0 & 17.9 & 20.9 & 20.7 \\
& $(3.4)$ & $(3.1)$ & $(4.9)$ & $(6.4)$ & $(6.6)$ \\
階段昇降 & 9.8 & 12.4 & 15.2 & 16.0 & 17.9 \\
& $(5.1)$ & $(3.7)$ & $(5.9)$ & $(5.1)$ & $(3.9)$ \\
可動域 & 24.3 & 23.8 & 24.0 & 24.1 & 25.3 \\
& $(1.8)$ & $(2.2)$ & $(2.1)$ & $(1.9)$ & $(2.7)$ \\
腫脹 & 8.1 & 8.1 & 6.6 & 8.3 & 8.8 \\
& $(3.1)$ & $(2.8)$ & $(3.0)$ & $(2.4)$ & $(2.2)$ \\
\hline 合計 & 56.7 & 60.3 & 63.6 & 69.3 & 72.8 \\
& $(8.9)$ & $(7.2)$ & $(9.3)$ & $(7.8)$ & $(8.7)$ \\
\hline
\end{tabular}

( ) : 標準偏差

については脱臼の問題もあり, 関節位置覚に関する注 目が高いが，同様に膝関節についても人工関節による 関節位置覚の変化は考えられる。膝膝関節の関節位置 覚については, 勒帯損傷症例について多くの検討がな されている。岡村らは5), 前十字勒帯 (ACL) 再建術症 例において勒帯損傷と関節固有感覚の関連を示し, 神 経筋再教育などの関節固有感覚を向上させる訓練の確 立と前十字勒帯損傷の予防の可能性を示している。岡 村ら ( ${ }^{6}$ 前十字勒帯損傷膝における膝関節固有感覚の 関与を検討するため, 高校バスケットボール部員 837 名 を前向きに観察し，膝関節位置覚の低下が ACL 損傷の 身体的素因の一つとなっている可能性を示している。 本研究の対象者は全例 ACL, PCL 切除されており, 関 節位置覚の低下を考慮する必要がある。このことから， 本研究は, 人工関節置換術後の関節位置覚の変化を明 らかにした点で有用といえる。 
表3 術後3週の関節位置覚得点に影響を与える因子の分散分析表

\begin{tabular}{|c|c|c|c|c|c|c|}
\hline & & 平方和 & 自由度 & 平均平方 & $\mathrm{F}$ 值 & 有意確率 \\
\hline \multirow[t]{3}{*}{ 年齢 } & 得点（高中低） & 56.578 & 2 & 28.289 & 0.584 & 0.564 \\
\hline & 誤差 & 1550.165 & 32 & 48.443 & & \\
\hline & 全体 & 1606.743 & 34 & & & \\
\hline \multirow[t]{3}{*}{ 術時間 } & 得点（高中低） & 6150.271 & 2 & 3075.135 & 1.337 & 0.282 \\
\hline & 誤差 & 55216.396 & 24 & 2300.683 & & \\
\hline & 全体 & 61366.667 & 26 & & & \\
\hline \multirow[t]{3}{*}{ 出血量 } & 得点（高中低） & 108622.234 & 2 & 54311.117 & 1.464 & 0.251 \\
\hline & 誤差 & 890241.396 & 24 & 37093.392 & & \\
\hline & 全体 & 998863.630 & 26 & & & \\
\hline \multirow[t]{3}{*}{ SLR 自立 } & 得点（高中低） & 0.443 & 2 & 0.222 & 0.267 & 0.767 \\
\hline & 誤差 & 26.528 & 32 & 0.829 & & \\
\hline & 全体 & 26.971 & 34 & & & \\
\hline \multirow[t]{3}{*}{ 術前 BMI } & 得点（高中低） & 52.692 & 2 & 26.346 & 1.137 & 0.333 \\
\hline & 誤差 & 741.309 & 32 & 23.166 & & \\
\hline & 全体 & 794.000 & 34 & & & \\
\hline \multirow[t]{3}{*}{$\begin{array}{l}\text { 歩行 } \\
\end{array}$} & 得点（高中低） & 7.619 & 2 & 3.810 & 0.434 & 0.652 \\
\hline & 誤差 & 280.952 & 32 & 8.780 & & \\
\hline & 全体 & 288.571 & 34 & & & \\
\hline \multirow[t]{3}{*}{ 階段昇降 } & 得点（高中低） & 315.411 & 2 & 157.706 & 8.288 & 0.001 \\
\hline & 誤差 & 608.874 & 32 & 19.027 & & \\
\hline & 全体 & 924.286 & 34 & & & \\
\hline \multirow[t]{3}{*}{ 可動域 } & 得点（高中低） & 3.853 & 2 & 1.926 & 0.953 & 0.396 \\
\hline & 誤差 & 64.719 & 32 & 2.022 & & \\
\hline & 全体 & 68.571 & 34 & & & \\
\hline \multirow[t]{3}{*}{ 腫脹 } & 得点（高中低） & 91.948 & 2 & 45.974 & 7.170 & 0.003 \\
\hline & 誤差 & 205.195 & 32 & 6.412 & & \\
\hline & 全体 & 297.143 & 34 & & & \\
\hline \multirow[t]{3}{*}{ JOA スコア計 } & 得点（高中低） & 750.173 & 2 & 375.087 & 5.989 & 0.006 \\
\hline & 誤差 & 2004.113 & 32 & 62.629 & & \\
\hline & 全体 & 2754.286 & 34 & & & \\
\hline
\end{tabular}

関節位置覚に注目した研究は多くなされている7-10) が，変形性膝関節症に対し膝関節置換術を施行した場 合の関節位置覚の変化についての報告は見あたらない ため, 本研究結果は新たな知見といえる。

関節位置覚得点の特徵は, 術後 3 週で最も低下し, そ の後時間の経過に伴い改善することが分かった。当院 のクリティカルパスでは, 術後3 週は歩行獲得し, 階段 動作, その他 ADL 動作についても自立し, 自宅退院す る時期である。しかしながら今回の研究結果から見る と, 手術の影響を大きく受けている時期であり, 腫脹
や，歩行時の痛みを訴える場合もある。

術後 3 週での関節位置覚低下に関与する要因を検討 するため, 関節位置覚得点を高中低の 3 群に分けて関 連要因を検討した。要因としては, 年齢, BMI などの 身体特性, 術前の膝関節機能, 術侵襲の関連が大きい と考え, 術後 3 週の関節位置覚の高中低別に, 各々の項 目の平均值を算出し比較を行った。その結果, 関節位 置覚得点が低い群では, 年齢が高い, BMI が高い, 術 中, 術後の出血量が多い, 術時間が長い, 皮切が大き いなどの傾向が認められた。なお, 統計学的な有意差 
表4 術後3週の関節位置覚得点に影響を与える因子の多重 比較 (平均值)

\begin{tabular}{|c|c|c|c|c|}
\hline & 低值群 & 中間群 & 高值群 & \\
\hline \multirow[t]{2}{*}{ 年齢 } & 72.4 & 74.0 & 69.7 & \\
\hline & 7.6 & 6.4 & 8.5 & \\
\hline \multirow[t]{2}{*}{ 術時間 } & 182.7 & 172.1 & 122.5 & \\
\hline & 28.0 & 60.3 & 10.6 & \\
\hline \multirow[t]{2}{*}{ 出血量 } & 402.7 & 303.6 & 186.0 & \\
\hline & 192.6 & 191.5 & 206.5 & \\
\hline \multirow[t]{2}{*}{ SLR 自立 } & 3.1 & 3.0 & 2.7 & \\
\hline & 0.8 & 1.0 & 0.6 & \\
\hline \multirow[t]{2}{*}{ 術前 BMI } & 29.6 & 27.8 & 25.2 & \\
\hline & 4.9 & 5.0 & 1.7 & \\
\hline \multirow[t]{2}{*}{ 歩行 } & 15.0 & 14.0 & 15.0 & \\
\hline & 4.5 & 2.0 & 0.0 & \\
\hline \multirow[t]{2}{*}{ 階段昇降 } & $6.8^{*, * *}$ & $12.1^{*}$ & $16.7 * *$ & $*: p=0.007$ \\
\hline & 4.6 & 4.4 & 2.9 & ${ }^{* *}: p=0.004$ \\
\hline \multirow[t]{2}{*}{ 可動域 } & 24.1 & 24.8 & 25.0 & \\
\hline & 2.0 & 1.1 & 0.0 & \\
\hline \multirow[t]{2}{*}{ 腫脹 } & $5.9^{\dagger}, \ddagger$ & $9.3^{\dagger}$ & $10.0^{\ddagger}$ & ${ }^{\dagger}: \mathrm{p}=0.003$ \\
\hline & 3.8 & 1.8 & 0.0 & ${ }^{\ddagger}: \mathrm{p}=0.048$ \\
\hline \multirow[t]{2}{*}{ JOA スコア計 } & $51.8^{\mathbb{I}, \#}$ & $60.2 \rrbracket$ & $66.7^{\#}$ & ๆ $: \mathrm{p}=0.020$ \\
\hline & 9.6 & 7.3 & 2.9 & ${ }^{\#}: \mathrm{p}=0.019$ \\
\hline
\end{tabular}

( ）: 標淮偏差

同じ記号は有意な差が見られた組み合わせを示す。

が認められた項目はBMI のみであった。JOA スコアに ついては, 歩行の項目を除き, 関節位置覚が低い群で, 得点が高い傾向が見られた。なお, 統計学的な有意差 が認められたのは, 階段昇降能力, 腫脹, スコア合計 点であった。

術侵襲が大きい場合は，関節位置覚の受容器を大き な範囲で除去していることになり, 関節位置覚得点の 低下は当然の結果と考えられる。術結果より, 関節位 置覚が低下寸ることを予測し, リスク管理, 改善のた めの, リ八項目の導入が必要と考えられる。

本研究結果は, 術前の活動状態が術後の関節位置覚 の高低に影響することを示している。関節位置覚の受 容器は関節内のみに分布するのではなく, 関節周囲組 織に多く分布していると考えられる。術前の活動性が 高く, これらを習慣的に使っている症例では手術侵襲 が加わった後にも代償機構が働きやすいため, 関節位 置覚の低下を来しにくいと考えられる。術前の膝の機 能的な低下については, 変形による痛みの増強, 腫脹 の増強などが大きく，関節を大きく動かすことが困難
な状態のものも多い。このため, 日常生活動作の中で 痛みのないものと同様に膝関節を使うことは困難であ る。しかしながら，痛みを回避するような状況（無荷 重の状態など）を設定しできるだけ多くの膝関節運動 をしておくことで, 術後の位置覚の低下を回避できる 可能性があると思われる。すなわち, 術前リハビリテー ションにより, 早期の関節位置覚の回復が得られる可 能性を示す結果として興味深い。

本研究では, 人工膝関節置換術においては退院時期 に相当する術後 3 週では著しい関節位置覚の低下が存 在する症例が多いこと, 術侵襲の程度や術前の膝関節 機能の程度が術後 3 週の位置覚の低下と関連すること が明らかとなった。この結果は, 術前・術直後のリ八 ビリテーションプログラムを考える上で, 関節位置覚 へのアプローチの必要性また可能性を再認識させるも のである。術後関節位置覚の早期回復に必要なリハビ リテーションの内容について検討し, その妥当性, 有 効性を検討していくことが今後の課題である。

\section{引用文献}

1) Kennedy JC, Alexander IJ, Hayes KC: Nerve supply of the human knee and its functional importance. Am J Sports Med, 1982, 10: 329-335.

2) 朝野裕一, 福田浩史 : 変形性膝関節症に対寸る術後理学療法 の工夫. Medical Rehabilitation(1346-0773), 2006, 63 : 51-56.

3) 中川法一, 嶋田智明, 阪本良太・他: THA 術後の関節位置 覚, 前向き研究. Hip Joint, 2004, 30 : 59-61.

4) 田篭慶一, 中川法一, 細井きみ江・他 : THA術後の関節位置 覚, 症例報告. Hip Joint, 2004, 30(10) : 56-58.

5) 岡村良久, 星 忠行, 平賀康晴-他: 膝前十字勒帯損傷（非 接触型）の原因と対策, 膝前十字勒帯損傷之関節固有感覚. 臨床スポーツ医学, 2002, 19(9) : 1011-1015.

6) 岡村良久, 星 忠行, 津田英一・他 : スポーツ外傷の最新の 知見と治療, 膝前十字勒帯損傷と関節固有感覚. 整形 - 災害 外科, 2003, 46(10): 1241-1246.

7) 杉原敏道, 郷 貴大, 三島誠一: 高齢者の関節位置覚測定で 信頼性を得るための測定回数に関する検討. 理学療法科学, 2005, 20(1) : 49-52.

8) 杉原敏道, 郷 貴大, 高橋玲子・他 : 角度設定する際の角速 度の相違による膝関節位置覚一の影響. 理学療法科学, 2004, 19(2) : 75-79.

9) 高見千由里, 西村育恵, 伊藤直樹 - 他 : 鏡視下半月板切除術 による膝関節位置覚と重心動摇の変化. 日本私立医科大学理 学療法学会誌, 2005, $22: 21-22$.

10) 嶋田誠一郎, 佐々木伸一, 北出一平・他 : 変形性膝関節症患 者における膝関節位置覚の横断的研究. 国立大学理学療法士 学会誌, 2004, 25 : 46-49. 